\title{
Prevention of Pine Wilt of Scots Pine (Pinus sylvestris) with Systemic Abamectin Injections
}

\author{
Randall James, Ned Tisserat, and Tim Todd
}

\begin{abstract}
We examined the efficacy of the insecticide/nematicide abamectin to prevent pine wilt disease caused by the pinewood nematode (Bursaphelenchus xylophilus) in Scots pine (Pinus sylvestris). Pinewood nematode movement was inhibited (>80\% death or paralysis) following a $48 \mathrm{hr}$ exposure to abamectin concentrations as low as $0.1 \mu \mathrm{L}$ a.i. per L (100 $\mathrm{ppb}$ ). A commercial formulation of abamectin (Avid ${ }^{\mathrm{TM}}$ ) was injected into Scots pine using a pressurized systemic trunk injection tube (STIT) technique. Fifteen to $30 \mathrm{~mL}(0.45$ to $0.90 \mathrm{fl} \mathrm{oz})$ of Avid per STIT could be injected into the trees in less than $1 \mathrm{hr}$. Trees were successfully injected throughout February, March, and April at temperatures above $4.4^{\circ} \mathrm{C}\left(40^{\circ} \mathrm{F}\right)$. Survival after 1 year of $10 \mathrm{~cm}$ diameter (4 in) at breast height (dbh) Scots pines injected with Avid and subsequently inoculated with pinewood nematode was higher $(75 \%)$ than in pines injected with water (42\%). Similarly, survival after 3 years of large Scots pines (30 to $60 \mathrm{~cm}$ [12 to $24 \mathrm{in}] \mathrm{dbh}$ )] injected with Avid and exposed to a natural epidemic of pine wilt was higher $(96 \%)$ than in noninjected pines $(33 \%)$ or those injected with water $(71 \%)$. These results indicate that preventive injections of Scots pine with Avid are effective in protecting against pine wilt disease.
\end{abstract}

Key Words. Abamectin; Avid; Bursaphelenchus xylophilus; pine wilt; pinewood nematode; Pinus sylvestris; Scots pine; tree injections.

Pine wilt, caused by the pinewood nematode (PWN) Bursaphelenchus xylophilus, is a lethal disease of Scots (Pinus sylvestris), Austrian (Pinus nigra), and other exotic and native pines growing in urban environments throughout the eastern and central United States (Wingfield et al. 1982, 1986; Gleason et al. 2000). The incidence of pine wilt in Kansas increased in 2001 to 2003 during a period of drought and high summer temperatures resulting in mortality of thousands of Scots and, in some cases, Austrian pines.

Pine wilt in the United States has been primarily managed by sanitation. Prompt removal and chipping or burning of dead pines reduces PWN inoculum and removes breeding areas for the pine sawyer (Monochamus spp.), which vectors the nematode. Unfortunately, sanitation is hard to implement over a wide geographic area. Thus, the pine wilt epidemic in many areas of the United States has continued unabated. In Japan, tree injection with emamectin benzoate has been successfully used to prevent pine wilt (Kazuya et al. 1999). This product is not currently labeled for pine wilt prevention in the United States. However, a closely related group of compounds called avermectins are commonly used as insecticides/miticides and have shown efficacy as nematicides (Blackburn et al. 1996). An avermectin called abamectin is labeled in the United States as Avid ${ }^{\mathrm{TM}}$ (Syngenta) for mite and insect control and may be a candidate for injecting pines to prevent pine wilt.
Various macro- and microinjection techniques have been developed and are widely used to treat insects, diseases, and nutrient deficiencies in trees. However, many of these injection techniques are not efficient in delivering liquid into pines. Holes drilled into pines quickly fill with oleoresin released by the tree in response to wounding (Grosman et al. 2002). Helson et al. (2001) developed a relatively simple injection device named the systemic tree injection tube (STIT) and successfully injected many conifer species with neem oil.

Our goal was to develop an effective injection technique for pine wilt control. We first determined the activity of abamectin on PWN in vitro. The second objective was to determine whether abamectin could be successfully injected into Scots pine using the STIT injection technique. Finally, the effectiveness of abamectin injections to prevent pine wilt in Scots pine was assessed.

\section{MATERIALS AND METHODS}

\section{Nematicidal Properties of Abamectin}

Pinewood nematode was extracted in water from branches and trunk sections of Scots pine collected in late stages of pine wilt and exposed to concentrations of abamectin. Details of the extraction process are provided by James (2005). Pinewood nematode numbers were adjusted to 2500 per $\mathrm{mL}$ 
$(0.03 \mathrm{fl} \mathrm{oz})$ water. The final suspension contained a mixture of life stages of PWN, a few other nematode species, and organic debris. Two $\mathrm{mL}(0.02 \mathrm{fl} \mathrm{oz})$ of the nematode suspension (approximately 5,000 nematodes) were pipetted into small glass Petri plates. A solution of Avid was added to obtain final concentrations of $0,0.01,0.1,1.0$, and $10.0 \mu \mathrm{L}$ a.i. abamectin per liter ( $\mathrm{ppm})$ water. Nematodes were soaked in the solution for $48 \mathrm{hr}$ at $20^{\circ} \mathrm{C}\left(68^{\circ} \mathrm{F}\right)$. The solutions containing nematodes were then poured over Kleenex-brand tissue suspended by a coarse screen in contact with the surface of tapwater contained in $10 \mathrm{~cm}$ (4 in) diameter pots (Alby 1975). Tissue margins were folded to prevent nematode passage into suspension without active movement through the tissue. After $24 \mathrm{hr}$, tissue and screens were removed and water in pots decanted to approximately $80 \mathrm{~mL}(2.7 \mathrm{fl} \mathrm{oz})$. Nematodes in the suspension were then counted as previously described. There were four replicates of each nematode/ abamectin concentration and the experiment was repeated. Data from the two experiments were combined for analysis. The number of active nematodes (i.e., those capable of migrating through the tissue) was standardized to the predicted $\mathrm{y}$ value at concentration 0 and modeled as an exponential function of abamectin concentration using Proc NLIN in SAS (SAS Institute 1999).

\section{Tree Injections Followed by Inoculations with Pinewood Nematode}

The efficacy of abamectin injections to suppress pine wilt was studied in an abandoned Scots pine Christmas tree farm near Lansing, Kansas. The experimental design was a randomized complete block with four treatments and 20 trees per treatment. Trees were approximately 4 to $6 \mathrm{~m}(13.2$ to $19.8 \mathrm{ft})$ in height with dbh of 7 to $15 \mathrm{~cm}$ (2.8 to 6 in). Injection methods included the Wedgle injector (Arbor Systems Inc., Omaha, NE) and systemic tree injection tubes (STIT) (Helson et al. 2001). Briefly, the Wedgle injector is a system consisting of a modified livestock syringe with a flattened, beveled needle that is inserted through the bark and to the cambium. A small amount of liquid $(0.5$ or $1 \mathrm{~mL})$ is deposited in the xylem/bark interface by squeezing two handles simultaneously to create pressure for injection. The STIT system consists of tubing (Nalgene ${ }^{\mathrm{TM}}$ or Tygon ${ }^{\mathrm{TM}}$ ) approximately 60 to $90 \mathrm{~cm}$ ( 2 to $3 \mathrm{ft})$ long, $1.7 \mathrm{~cm}(0.68 \mathrm{in})$ outside diameter, and $1.0 \mathrm{~cm}(0.4 \mathrm{in})$ inside diameter. One end of the tube is connected to a maple sap spile (Atkinson Supply, Oro Station, Ontario, Canada) and the other to a tubeless automobile tire stem by automobile hose clamps. Trees are injected by drilling $8 \mathrm{~mm}(0.32 \mathrm{in})$ diameter holes at a slight angle into the trunk to a depth of 3 to $4 \mathrm{~cm}$ (1.2 to 1.6 in). The maple spile with attached hose (without the tire stem) is inserted into the hole and tapped with a hammer to seat into place. Material for injection is loaded into the attached hose by a syringe, the tire stem inserted and then secured with a hose clamp.
A bicycle pump is used to pressurize the tube to $\approx 275 \mathrm{kPa}$ (40 psi).

Injections were performed 18 May 2002. A 2\% a.i. formulation of abamectin (Avid ${ }^{\mathrm{TM}}$; Syngenta Corporation) or water was injected with the Wedgle at a rate of $1 \mathrm{~mL}$ per $3-\mathrm{cm}$ diameter (dbh) ( $0.03 \mathrm{fl} \mathrm{oz}$ per $1.2 \mathrm{in})$. Thus, a total of $5 \mathrm{~mL}$ $(0.15 \mathrm{fl} \mathrm{oz})$ of liquid was injected into trees at five injection points equally spaced around the tree circumference at ground level. Avid or water was injected with the STIT system at $30 \mathrm{~mL}(0.9 \mathrm{fl} \mathrm{oz})$ per $15 \mathrm{~cm}(6$ in) trunk diameter with an additional $30 \mathrm{~mL}$ ( $0.9 \mathrm{fl} \mathrm{oz}$ ) for each $5 \mathrm{~cm}$ (2 in) diameter. Because all trees in the planting were $15 \mathrm{~cm}(6$ in) dbh or smaller, all trees were injected with $30 \mathrm{~mL}(0.9 \mathrm{fl} \mathrm{oz})$ of liquid. Two STIT tubes at $15 \mathrm{~mL}(0.5 \mathrm{fl} \mathrm{oz})$ per tube were inserted at ground level and on opposite sides of the trunk. All trees were inoculated with PWN on 20 June 2002. Inoculum from a single dead Scots pine was prepared by sectioning the trunk into $2 \mathrm{~cm}(0.8 \mathrm{in})$ thick wafers. The wafers were debarked and chipped into smaller pieces and put in $\approx 18 \mathrm{~L}$ (4.68 gal) buckets filled with water and agitated with compressed air for $48 \mathrm{hr}$. Nematodes were processed as previously described to produce a suspension containing 4,733 \pm 159 nematodes per $\mathrm{mL}(0.03 \mathrm{fl} \mathrm{oz})$ water. Inoculation involved cutting the end of two 1 to $1.5 \mathrm{~cm}(0.4$ to 0.6 in) diameter healthy branches at a height of $\approx 2 \mathrm{~m}(6.6 \mathrm{ft})$ on opposite sides of each tree and drilling a $5 \mathrm{~mm}$ ( 0.2 in) diameter hole to a depth of 4 to $5 \mathrm{~cm}$ (1.6 to 2 in). One-half milliliter $(0.015 \mathrm{fl} \mathrm{oz})$ of the nematode suspension was pipetted into the hole. The wound was then capped with a plastic or rubber bung. Additionally, a third branch on each tree in 10 replicates was wounded in the manner previously described and capped but was not inoculated with the nematode suspension.

Visual symptom ratings for the entire tree were assigned on 6 December 2002 per the following rating scale: $1=$ healthy, $2=<25 \%$ dieback, $3=25 \%$ to $50 \%$ dieback, $4=50 \%$ to $75 \%$ dieback, and $5=$ complete mortality. Ratings for each treatment were separated $(P \leq 0.05)$ by the Kruskal-Wallis $\mathrm{K}$-sample test, a one-way analysis of ranks using Proc Rank and Proc GLM in SAS.

Branch samples 12 to $18 \mathrm{~cm}$ (4.8 to $7.2 \mathrm{in}$ ) in length were removed from all trees on 6 December 2002. Three samples were collected at the tip and base of an inoculated branch and one from the middle of a noninoculated branch on the opposite side from trees with damage ratings of 1 to 4 (no symptoms to major dieback). Two samples, including one from the base of the inoculated branch and one from middle of a noninoculated branch on the opposite side, were taken from trees with a rating of five (dead). Samples were placed in plastic bags and kept in cold storage at $4^{\circ} \mathrm{C}\left(39.2^{\circ} \mathrm{F}\right)$ before nematode extraction.

Extraction and counting procedures were conducted as previously described. After extraction, wood samples were oven- 
dried at $50^{\circ} \mathrm{C}\left(122^{\circ} \mathrm{F}\right)$ for 3 to 5 days. The number of nematodes per gram of dry wood for each treatment was calculated, $\log _{10}$-transformed, and means separated $(P \leq 0.05)$ according to least squares means (Proc GLM and LSMEANS in SAS). The number of nematodes per gram of dry wood was back-transformed for presentation.

Injections were repeated in 2003 at a second abandoned Scots pine Christmas tree planting located approximately 30 $\mathrm{km}(18 \mathrm{mi})$ southwest of the first site in Kansas City, Kansas, U.S. Trees ranged from 4 to $6 \mathrm{~m}$ (13.2 to $19.8 \mathrm{ft}$ ) in height and 7 to $15 \mathrm{~cm}$ (2.8 to 6 in) dbh. Approximately $5 \%$ of the trees in the planting had died from pine wilt before the experiment.

Trees were injected on 16 April 2003 with $30 \mathrm{~mL}(0.9 \mathrm{fl}$ oz) of Avid or water using the STIT injection device as previously described. The Wedgle injection system used at the Lansing site was not repeated in this study. Injected trees were inoculated with PWN on 20 June 2003 as previously described except at a concentration of 5,293 \pm 47 nematodes per $\mathrm{mL}(0.03 \mathrm{fl} \mathrm{oz})$. A control treatment consisting of nonwounded, noninjected trees was also inoculated. A set of trees inoculated in June received a curative injection of $30 \mathrm{~mL}(0.9$ $\mathrm{fl} \mathrm{oz}$ ) Avid on 20 July 2003. The experimental design was a randomized complete block with 20 trees per treatment.

Visual ratings and sample collections were made on 12 December 2003. All data were collected and analyzed as described for Experiment 1.

\section{Preventive Injections of Mature, Noninoculated Trees}

The efficacy of Avid on larger, more mature Scots pines ranging in diameter from 30 to $60 \mathrm{~cm}$ dbh (12 to 24 in) was evaluated at a cemetery site in Manhattan, Kansas. In May 2002, 58 trees were identified for injection and were paired based on their proximity. One tree in each pair was randomly selected and injected with Avid using STIT; the other tree was injected with water. In 2003, an additional 56 trees were paired and treated in a similar manner except that in 12 of the pairs; the control trees were not wounded or injected with water. Trees were injected with Avid or water at $30 \mathrm{~mL}(0.9$ $\mathrm{fl} \mathrm{oz})$ up to $15 \mathrm{~cm}(6 \mathrm{in}) \mathrm{dbh}$ and an additional $30 \mathrm{~mL}$ ( $0.9 \mathrm{fl}$ oz) for each additional $5 \mathrm{~cm}$ ( $2 \mathrm{in}) \mathrm{dbh}$. The number of STIT units used per tree varied and depended on the total volume of liquid to be injected. In all cases, $50 \mathrm{~mL}(1.5 \mathrm{fl} \mathrm{oz}$ ) liquid or less were injected with each tube. Thus, most trees required five to six STIT units. The units were spaced roughly equidistant around the circumference of the trunk near ground level but not in exposed roots. A final enumeration of live and dead trees for each treatment was made on 16 December 2004. When possible, samples were collected from dead trees before removal to test for the presence of PWN. Frequencies of live versus dead trees were compared among treatments by a $\chi^{2}$ test using Proc Freq in SAS.

\section{RESULTS}

\section{Abamectin Nematicidal Properties}

Abamectin at concentrations $>1 \mu \mathrm{L}$ per $\mathrm{L}(1 \mathrm{ppm})$ almost completely suppressed nematode migration through paper tissue, whereas concentrations of $0.1 \mu \mathrm{L}$ per $\mathrm{L}(100 \mathrm{ppb})$ resulted in an $80 \%$ reduction in activity (Figure 1). The effective abamectin concentration to reduce nematode activity by $50 \%\left(\mathrm{EC}_{50}\right)$ was $0.05 \mu \mathrm{L}$ a.i. per $\mathrm{L}(50 \mathrm{ppb})$.

\section{Field Injections Followed by Inoculation with Pinewood Nematode}

Trees injected with Avid did not exhibit phytotoxicity. Mean damage rating of the STIT-Avid treatment in the first experiment was lower $(P \leq 0.05)$ than ratings for the Wedgle-Avid and Wedgle-water but not for the STIT-water treatment (Figure 2). The STIT-Avid treatment also resulted in fewer ( $P \leq$ $0.05)$ nematodes per gram of wood than Wedgle-Avid or Wedgle-water treatment (Figure 3). In the second experiment, STIT-Avid-treated trees exhibited fewer pine wilt symptoms $(P \leq 0.05)$ than those of all other treatments (Figure 4) The STIT-Avid treatment resulted in fewer nematodes per gram of wood than the noninjected controls or the STITAvid curative (Figure 5). Combined survival rates from the Lansing and Kansas City locations 1 year after inoculation were $75 \%$ for the STIT-Avid, $42 \%$ for the STIT-water, and $25 \%$ for no injection (Kansas City site only) treatments.

\section{Preventive Injections of Mature Trees}

Only two of 57 (4\%) STIT-Avid-injected trees died over a 2 year period versus 13 of 45 (29\%) STIT-water-injected and eight of $12(67 \%)$ nontreated trees (Figure 6). Thirteen of 21 (62\%) wood samples taken from trees that died over the 3 year period (two trees not sampled because of city removal and disposal before collection) contained PWN.

\section{DISCUSSION}

In developing an injection technique to control PWN, it was necessary to identify a chemical that is widely available to

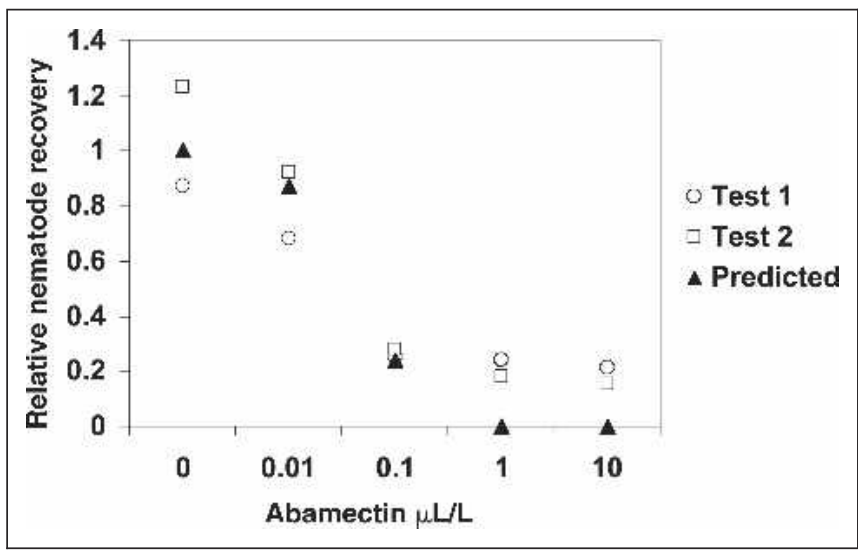

Figure 1. Relative recovery of pinewood nematode after $48 \mathrm{hr}$ exposure to concentrations of abamectin. 


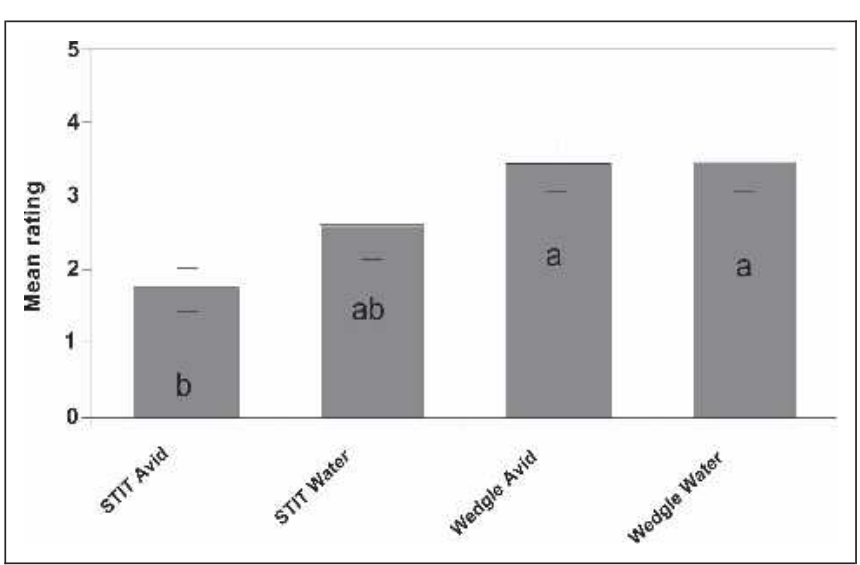

Figure 2. Mean damage rating $(1=$ healthy, $2=<25 \%$ dieback, $3=25 \%$ to $50 \%$ dieback, $4=51 \%$ to $75 \%$ dieback, 5 = dead) of Scots pine in December 2002 after injections in May 2002 and inoculations with pinewood nematode in June 2002. Means with same letter are not significantly different according to LSMEANS $(P \leq 0.05)$ by Kruskal-Wallis $\mathrm{K}$-sample test of one-way analysis of ranks.

arborists, nematicidal at low concentrations, relatively nontoxic to humans, persistent, and formulated to facilitate easy injection. Avid, which belongs to a class of insecticides called the avermectins, has many of these features. It is currently labeled in the United States to control a wide variety of arthropod pests, including mites on pines, when applied as a foliar spray. We found that abamectin was inhibitory to PWN in vitro at concentrations as low as $0.01 \mu \mathrm{L}$ per $\mathrm{L}(10 \mathrm{ppb})$. Avid activity against nematodes at low concentrations is critical because it allows for injection of relatively small quanti-

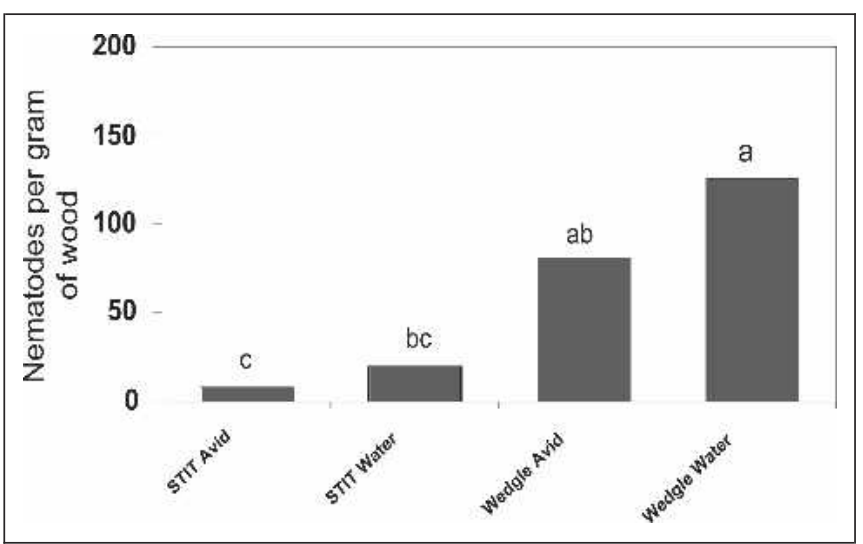

Figure 3. Mean number of pinewood nematodes per gram of wood in December 2002 after injections in May 2002 and inoculations in June 2002. Means with the same letter are not significantly different according to LSMEANS $(P \leq 0.05)$. Data were $\log _{10}$-transformed for analysis and back-transformed for presentation.

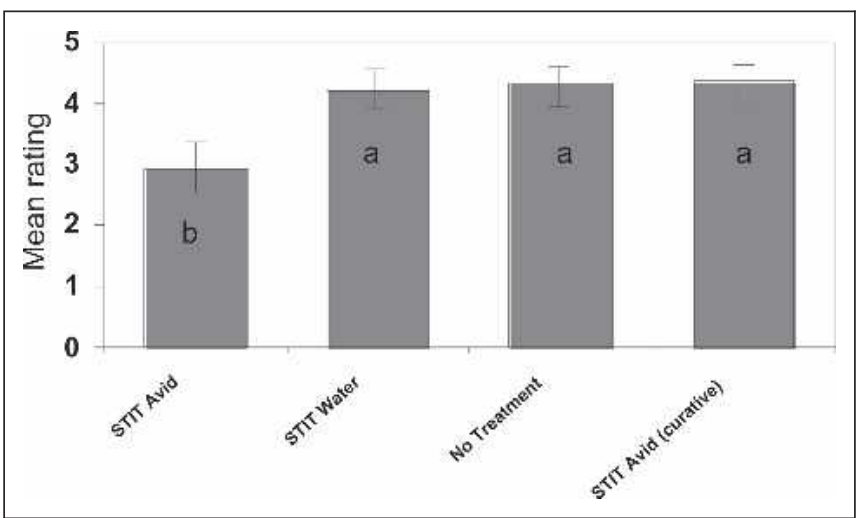

Figure 4. Mean damage rating ( $1=$ healthy, $2=<25 \%$ dieback, $3=25 \%$ to $50 \%$ dieback, $4=51 \%$ to $75 \%$ dieback, 5 = dead) of Scots pine in December 2003 after injections in April 2003 and inoculations with pinewood nematode in June 2003. Means with same letter are not significantly different according to LSMEANS $(P \leq 0.05)$ by Kruskal-Wallis $\mathrm{K}$-sample test of one-way analysis of ranks.

ties of the chemical into large tree volumes. A major obstacle associated with pine injections has been the difficulty of introducing large volumes of liquid into the xylem. Thus, injection of relatively small amounts of undiluted Avid resulted in concentrations effective in suppressing PWN.

Several macro- and microinjection techniques are currently available. One problem associated with many injection devices is that they do not provide enough external pressure to

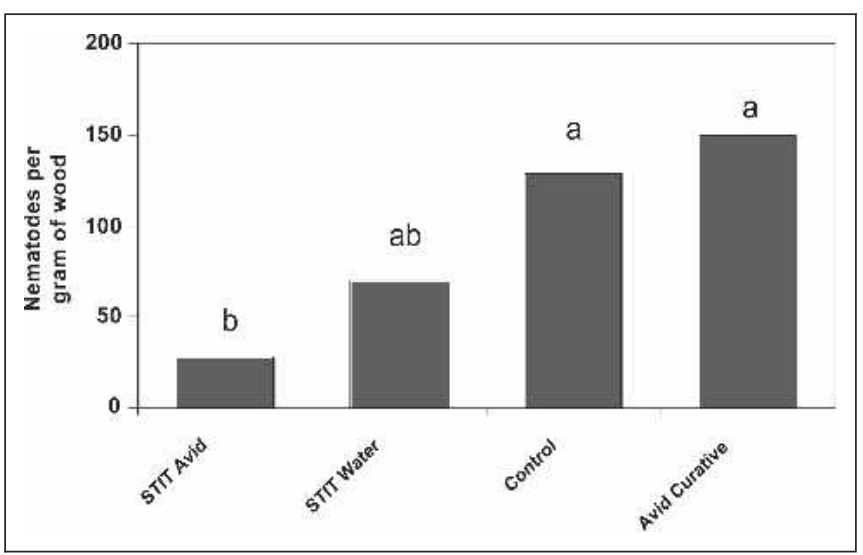

Figure 5. Mean number of pinewood nematodes per gram of Scots pine wood in December 2003 after injections in April 2003 and inoculations in June 2003. Curative injections were performed in July after April inoculation. Means with the same letter are not significantly different according to LSMEANS $(P \leq 0.05)$. Data were $\log _{10^{-}}$ transformed for analysis and back-transformed for presentation. 


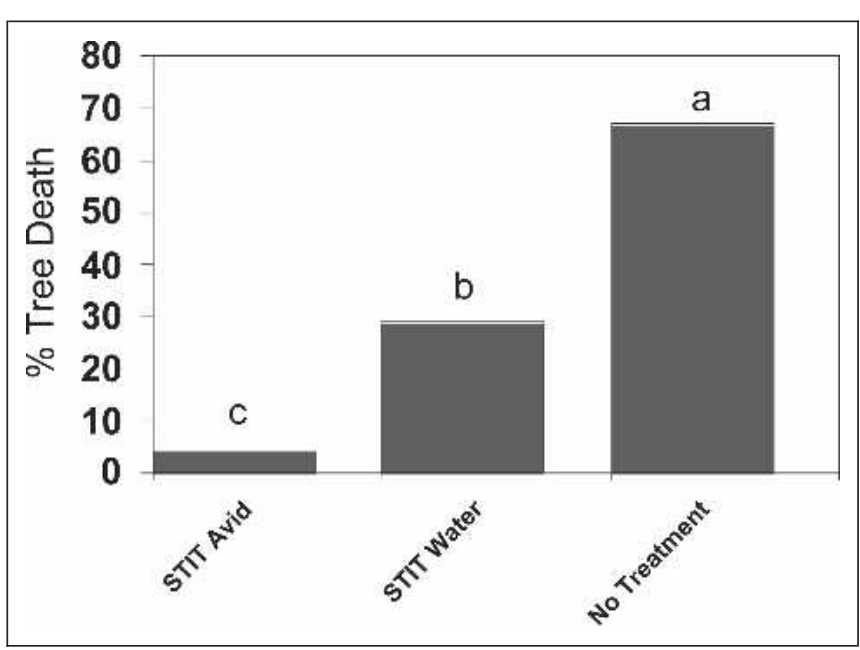

Figure 6. Percentage of dead mature Scots pines in December $\mathbf{2 0 0 4}$ at a Manhattan, Kansas, cemetery with a natural epidemic of pine wilt after Avid injections in May 2002 and 2003. Values with different letters are significantly different according to $\chi^{2}$ analysis $(P \leq 0.05)$.

overcome blockage of conifer xylem by resin after wounding. In principle, the Wedgle injector that was used in the first experiment attempts to avoid this problem by injecting product into the cambial/bark tissue rather than directly into the tracheids of the xylem, thus avoiding problems with resin flow. However, the overlapping, plate-like bark of Scots pine resulted in consistent leakage of water and Avid between bark cracks after injection. Therefore, the Wedgle injector was unsuitable for injection of pines. In contrast, the STIT system was an effective method of injecting Scots pine. Injections of 30 to $50 \mathrm{~mL}$ ( 0.9 to $1.5 \mathrm{fl} \mathrm{oz}$ ) of Avid per tube into Scots pine occurred in less than $1 \mathrm{hr}$ and often more rapidly. There was no indication of blockage of the injection hole by resin or leakage. We found no evidence of internal discoloration at injection sites after tree removal.

Our results indicate that Avid concentrations inside the tree were sufficient to suppress PWN; however, the concentration, distribution, and persistence of the chemical within the tree are not known. For example, it is not known whether Avid was localized within the wood of the trunk and large branches or whether it migrated to shoots and needles as well.

Injections with Avid were effective in increasing the survival rates of Scots pines that were artificially inoculated with PWN. Considering the aggressive inoculation method used here, and large quantities of nematodes introduced in the host, the apparent ability of Avid to prevent development of PWN was encouraging. Natural introduction of nematodes into wood tissue during maturation feeding of cerambycid beetles (Monochamus spp.) may well be less efficient (Linit 1987), suggesting that a higher survival rate of naturally infected trees may occur. Preventive injections of noninoculated ma- ture trees at the cemetery supported this hypothesis. Only $4 \%$ mortality occurred in pines injected with Avid compared with $37 \%$ of those not treated with Avid. Pinewood nematode was only detected in $62 \%$ of wood samples collected from dead trees at the cemetery. However, these samples were taken from the lower trunk as a result of the unreachable height of symptomatic branches. We found (data not shown), as did Malek and Appleby (1984), that higher nematode densities were usually present in the upper trunk or branch wood. Thus, the percentage recovery of PWN might have been higher if samples would have been collected in upper portions of the tree.

Postinfection injections of Avid were not effective in suppressing pine wilt. These results are consistent with developmental studies of pine wilt after inoculation. For example, oleoresin production stopped in less than 20 days after inoculation, and rapid irreversible disease symptoms occurred before nematode population increases (Mamiya 1972). Although the exact pathologic mechanism is still unknown, it is clear from this study that infection during the growing season by PWN results in swift disease development, explaining why curative treatments were unsuccessful.

A puzzling result from the injection studies was the apparent enhanced survival of pines injected with water compared with noninjected trees. The amount of water injected was negligible in comparison to available soil moisture at the time of our injection (April). Thus, it is unlikely the water alone was responsible for increased survival. Alternatively, the results might be explained by some type of induced resistance to PWN resulting from wounding during the injection process. An induced resistance response after wounding is well documented in plants (Sticher et al. 1997). Krokene et al. (2000) demonstrated localized enhanced resistance in Scots pine to blue stain fungi after branch wounding.

We were intrigued by the observation that some noninjected and water-injected Scots pine trees survived up to three inoculations with PWN over a 2 year period (data not shown). These results might be explained by the induced resistance response previously described or indicate that genetic variability in susceptibility to the PWN exists. The survival of individual Scots pines in windbreaks and urban plantings decimated by pine wilt over the past several years in Kansas also supports the conclusion genetic resistance may be present. We are in the process of grafting trees that survived multiple inoculations with PWN for further resistance screening.

Loss of Scots pine to pine wilt in the midwestern United States continues at an alarming rate. Past control recommendations of sanitation or minimizing stress through irrigation or improved fertility have been largely ineffective in managing the disease. We believe that preventive injections of abamectin can help protect Scots pine from pine wilt and offers 
hope for the preservation of certain mature Scots pine in landscapes where the disease is prevalent.

Acknowledgments. This research was supported by grants from the Kansas Arborist's Association and the Tree Fund's John Z. Duling Research Fund. We thank J. David-Maddox and arborists of the Manhattan Kansas Park and Recreation

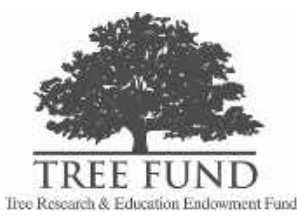
staff for their assistance in this study. We also thank Mark Kottwitz, Kansas City Kansas Parks Department, for assistance.

\section{LITERATURE CITED}

Alby, T. 1975. The incidence and host parasite relationships of selected nematodes and forage grasses. M.S. Thesis, Oklahoma State University, Stillwater, OK.

Blackburn, K., S.R. Alm, and T.S. Yeh. 1996. Avermectin $\mathrm{B}_{1}$, Isazofos, and Fenamiphos for control of Hoplolaimus geleatus, and Tylenchorhynchus dubius infesting Poa anпиа. Journal of Nematology 28:694-697.

Gleason, M., M. Linit, Z. Narjess, P. Donald, N. Tisserat, and L. Giesler. 2000. Pine Wilt: A Fatal Disease of Exotic Pines in the Midwest. Iowa State University, Kansas State University, University of Missouri, University of Nebraska collaborative bulletin.

Grosman, D.M., W.W. Upton, F.A. McCook, and R.F. Billings. 2002. Systemic insecticide injections for control of cone and seed insects in loblolly pine seed orchards- 2 year results. Southern Journal of Applied Forestry 26: 146-152.

Helson, B., D.B. Lyons, K. Wanner, and S.A. Taylor. 2001. Control of conifer defoliators with neem-based systemic bioinsecticides using a novel injection device. The Canadian Entomologist 133:729-744.

James, R. 2005. Prevention of pine wilt of Scots pine with systemic abamectin injections. M.S. Thesis, Kansas State University, Manhattan, KS.

Kazuya, T., T. Soejima, T. Suzuki, and K. Kawazu. 1999. Studies on development of a novel trunk-injection agent against the pine wilt disease. Pest Management Science 56:10.

Krokene, P., H. Solheim, and B. Langstrom. 2000. Fungal infection and mechanical wounding induce resistance in Scots pine. European Journal of Plant Pathology 106: 537-541.

Linit, M.J. 1987. The Insect Component of Pine Wilt Disease in the United States. Pathogenicity of the Pine Wood Nematode. APS Press, St. Paul, MN.

Malek, R., and J. Appleby. 1984. Epidemiology of pine wilt in Illinois. Plant Disease 68:180-187.

Mamiya, Y. 1972. Reproduction of pine lethal wilting disease by the inoculation of young trees with Bursaphelenchus lignicolus [in Japanese with English summary]. Japanese Journal of Nematology 2:40-44.

SAS Institute. 1999. SAS/STAT User's Guide, Version 8, Volumes 1, 2, \& 3. SAS Institute Inc. Cary, NC.

Sticher, L., B. Mauch-Mani, and J.P. Metraux. 1997. Systemic acquired resistance. Annual Review of Phytopathology 35:235.

Wingfield, M.J., P.J. Bedker, and R.A. Blanchette. 1986. Pathogenicity of Bursaphelenchus xylophilus on pines in Minnesota and Wisconsin. Journal of Nematology 18: 44-49.

Wingfield, M.J., R.A. Blanchette, T.H. Nicholls, and K. Robbins. 1982. Association of pine wood nematode with stressed trees in Minnesota, Iowa, and Wisconsin. Plant Disease 66:934-937.

\section{Randall James}

Owner and Consulting Arborist

Growing Concerns, Inc.

Manhattan, KS 66502, U.S.

Ned Tisserat (corresponding author)

Extension Specialist and Professor

Bioagricultural Sciences and Pest Management

Plant Sciences Bldg.

Colorado State University

Ft. Collins, CO 80523, U.S.

Ned.Tisserat@colostate.edu

Tim Todd

Nematologist

Department of Plant Pathology

Kansas State University

Manhattan, KS 66502, U.S.

Zusammenfassung. Wir untersuchten die Effektivität von dem Insektizid/Nematizid Abamectin, um die Kiefernwelke, die durch die Nematode Bursaphelenchus xylophilus in der Gemeinen Kiefer verursacht wird, zu verhindern. Die Bewegungen der Kiefernnematode waren Nachdem die Nematoden 48 Stunden einer Abamectinlösung mit $0,1 \mu l$ a.i. per liter (100 ppb ausgesetzt waren, war die Bewegung deutlich eingeschränkt (> 80\% Tod oder Paralyze). Mittels einer auf Druck basierenden Stamminjektion (STIT) wurde ein handelsübliches Abamectin-Präparat $\left(\right.$ Avid $\left.^{\mathrm{TM}}\right)$ in die Kiefern eingebracht. Bei dieser Methode können 15 to $30 \mathrm{ml}$ von Avid in weniger als 1 Stunde in den Baum injiziert werden. Die Bäume wurden erfolgreich in den Monaten Feb. März und April bei Temperaturen von $4,4^{\circ} \mathrm{C}$ behandelt. Das Überleben nach einem Jahr von Kiefern mit $10 \mathrm{~cm}$ BHD, Abamectin-Behandlung und subsequenter Nematodeninokulation war höher $(75 \%)$ als die mit Wasser behandelten Kontrollbäume (42\%). Ähnlich lag die Überlebensrate nach drei Jahren bei den großen Kiefern mit 30 to $60 \mathrm{~cm}$ BHD, mit Avid behandelt und einer natürlichen Epidemie von Kiefernwelke ausge- 
setzt, höher (90\%) als die nicht-injezierten Kiefern (33\%) oder die mit Wasser behandelten Bäume (71\%). Diese Ergebnisse, das präventive Avid-Injektionen bei Kiefern gegen Kiefernwelke schützen können.

Resumen. Se examinó la eficacia del insecticida/nematicida abamectin para prevenir la enfermedad de marchitamiento del pino por el nemátodo de la madera (Bursaphelenchus xylophilus) en pino Scots (Pinus sylvestris). El movimiento del nemátodo fue inhibido (>80\% muerte o parálisis) las 48 horas siguientes a la exposición a concentraciones de abamectin de $0.1 \mu l$ a.i. por litro (100 ppb). Una formulación comercial de abamectin (Avid ${ }^{\mathrm{TM}}$ ) fue inyectada en pino Scots usando la técnica de inyección sistémica presurizada (STIT, por sus siglas en inglés). Quince a $30 \mathrm{ml}$ (1/2 to $1 \mathrm{fl} \mathrm{oz}$ ) de Avid por
STIT fueron inyectados en los árboles en menos de 1 hora. Los árboles fueron inyectados exitosamente en Febrero, Marzo y Abril a temperaturas arriba de $4.4^{\circ}\left(40^{\circ} \mathrm{F}\right)$. La sobre vivencia después de un año de pinos Scots de $10 \mathrm{~cm}$. (3.9 pulg.) a la altura del pecho (dbh, por sus siglas en inglés) inyectados con Avid y subsecuentemente inoculados con el nemátodo fue más alta (75\%) que los pinos inyectados con agua (42\%). Similarmente, la sobre vivencia después de 3 años de pinos Scots grandes [30 to $60 \mathrm{~cm}$. (11.8 to 23.62 pulg.) dbh] inyectados con Avid y expuestos a un epidémico natural de marchitamiento del pino fue más alta $(96 \%)$ que en pinos no inyectados $(33 \%)$ o inyectados con agua $(71 \%)$. Estos resultados indican que las inyecciones preventivas de pinos Scots con Avid son efectivas para protegerlos contra la enfermedad. 